\title{
DynamicDye - Desenvolvimento de Naftopiranos Sensíveis à Luz com Maior Velocidade de Coloração/Descoloração
}

\section{Vasco Bonifácio}

vasco.bonifacio@tecnico.ulisboa.pt
Os corantes fotocrómicos são capazes de desenvolver cores intensas quando expostos à radiação UV e voltar ao estado inicial incolor na ausência de luz. Nos últimos 30 anos a indústria das lentes oftálmicas sintetizou centenas destes compostos, especialmente naftopiranos, e aplicou-os, com sucesso, em revestimentos finos na superfície das lentes produzindo lentes fotocromáticas que escurecem em função da intensidade da luz solar direta. Por detrás deste fenómeno está uma reação de fotoisomerização, reversível, que altera profundamente a estrutura e propriedades destes compostos.

As lentes atuais desenvolvem cores intensas (castanho e cinzento) muito rapidamente (30 s) mas descoram lentamente no escuro (cerca de $8 \mathrm{~min}$ ). Este processo de descoloração lento é devido ao facto de todos os naftopiranos utilizados pela indústria originarem duas espécies coradas, com diferentes estabilidades térmicas, sendo a mais estável minoritária, mas responsável pela persistência de uma cor residual no escuro. Este problema pode ser ultrapassado mediante uma alteração estrutural que impede especificamente a formação da espécie corada indesejada, com maior tempo de vida. Todavia, o desenvolvimento de um composto fotocrómico, industrialmente interessante, exige também que o mesmo seja fácil de sintetizar, incolor, solúvel em materiais poliméricos, muito sensível ao sol, desenvolva uma coloração neutra e seja capaz de fazer inúmeros ciclos de coloração/descoloração sem significativa degradação.

Estes requisitos, por vezes inconciliáveis, requerem o desenho de naftopiranos com uma estrutura em que cada substituinte tem um efeito particular, seja para garantir uma intensa absorção no visível, controlar a cinética de descoloração (2 min) ou impedir a formação das espécies lentas. Este projeto pretende sintetizar tais moléculas em poucas etapas e avaliar a sua viabilidade industrial, sendo desenvolvido em parceria com uma empresa portuguesa (POLO S.A.) que fabrica este tipo de lentes oftálmicas.

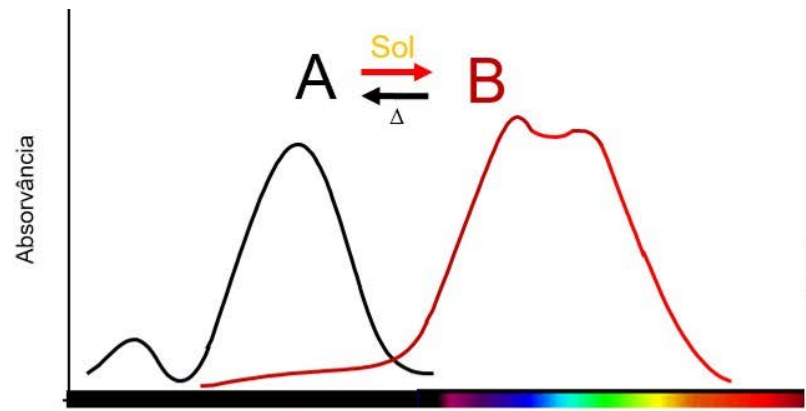

VIS

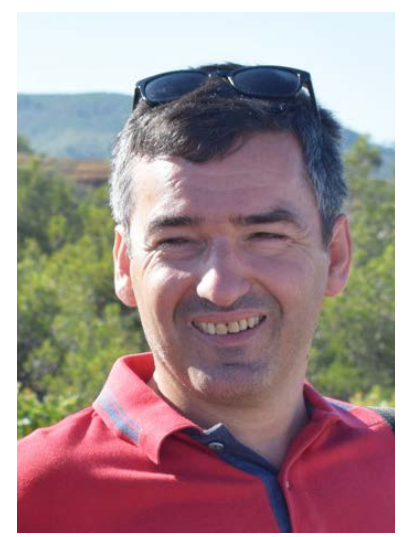

$>$

Ficha Técnica do projeto

Paulo Coelho

Acrónimo: DynamicDye

Referência: PTDC/QUI-QOR/28532/2017

Financiamento: Fundação para a Ciên-

cia e a Tecnologia (FCT).

Equipa: Universidade de Trás-os-Montes

e Alto Douro - Paulo Coelho (IR), Maria do

Céu Sousa, Vânia Graça; POLO S.A. - André

Polónia, Manuel Guimarães. 